\title{
An Analysis The Impact Of Modern Gamalama Plaza Contraction To The Traffic Movement
}

\author{
Risval Tribudiyanto*, Abdul Gaus, Nurmayasa Marsaoly \\ Department of Civil Engineering, Faculty of Engineering, Universitas Khairun, 97718, Ternate, Indonesia
}

\begin{abstract}
In this study, a descriptive method was used. From 15 equations tested, the value of $\mathrm{Y}=$ $2.64080272306193 \mathrm{X} 2+4.05031889744212 \mathrm{E}-06 \mathrm{X} 3+0.0882328648259467 \mathrm{X} 4+0.752392757509762 \mathrm{X} 5+$ 22.7120066091058 with $\mathrm{r}$ and $\mathrm{R}$ values was 0.543 , determinant coefficient was 0.548 , significant value was 0.000 and f-count value was 111.886 . From this equation, we found that the number of visitor attractions to Modern Plaza Gamalama is 15778 visitors, also increases to 17600 and 19622 for the next 5 years and 10 years. For the peak hour analysis, the volume of vehicles for the traffic was on monday at $16.00-17.00$ WIB with $2515.4 \mathrm{pcu} /$ hour capacity. The peak hour volume of vehicles was $1630.6 \mathrm{pcu} / \mathrm{hour}$, while the peak hour volume after the square operated was $2123.32 \mathrm{pcu} /$ hour for Pahlawan Revolusi Street and 3802.2 pcu/hour at Nukila Street. The provided parking capacity for four-wheeled vehicles at Plaza Gamalama Modern is for 60 cars, which cannot accommodate visitor vehicles parking. This is seen by the turnover of the four-wheel parking capacity at the beginning of the operation, namely $1.95>1.00$. For the next 5 years, it will be $3.03>1.00$. Meanwhile, for the next 10 years, it will be $4.70>1.00$.
\end{abstract}

Keywords: Traffic impact analysis, Determinant coefficient, Significant value

\section{Introduction}

In Indonesia's Law No. 22/2009, traffic is defined as the movement of vehicles and people in the road traffic space, while road traffic space is infrastructure intended for the movement of vehicles, people, and/or goods. The development in an area, such as the development of Plaza Gamalama Modern, can cause changes in the traffic condition around it. This occurs because of changes in land use which result in the changes in traffic flows in and out of the location so that it affects the pattern of transportation services in the area concerned.

The changes in traffic in a certain area are caused by the presence of a new activity center which then causes traffic generation and affects the existing traffic around the new activity center [1]. Ternate as the center of the economic activities in North Maluku is a rapidly growing city. Therefore, the government must provide facilities and infrastructure to support the growth of this city. In terms of urban development, the most prominent and rapidly growing is the shopping center or plaza through the construction of adequate and affordable economic facilities to support the development of this city.

To coordinate the needs of the community, the government of Ternate is building an economic center facility in the downtown of this city, namely Plaza Gamalama Modern, to meet the needs of the people of Ternate. Based on these conditions, the government of Ternate must make binding regulations based on traffic impact analysis as a condition for the construction of shopping centers or large-scale activity centers that have the potential to increase the burden of road capacity which must be adjusted to the Traffic Impact Analysis (Indonesian: Analisis Dampak Lalu Lintas (ANDALALIN)). This traffic impact analysis can be used as material for evaluating road performance around the activity center and can provide the best solution to overcome traffic problems in the area.

\section{Methods}

In this study, the researchers applied a descriptive method by outlining the facts as they are and then analyzing them to gain a conclusion or new concept about the object being studied. This study began by collecting literature and secondary data related to the research object. It was then continued by field surveys to collect primary data through distributing questionnaires and surveys concerning the traffic volume. This study was conducted in Ternate, specifically at Plaza Gamalama Modern, Jalan Revolution, and Jalan Nukila.

\subsection{Traffic Volume / Traffic Flow}

Traffic volume is the number of vehicles that pass a certain point of a road segment during a certain time. The type of volume analyzed in this study was the peak hour volume. The peak hour volume is the number of vehicles that pass a certain point on a road segment for one hour when the largest traffic flow occurs in one day. 
For analysis purposes, the surveyed vehicles were classified [2] as follows.

a. Light vehicles (LV), consisting of passenger cars, jeeps, sedans, minibusses, pick-ups, and others;

b. Heavy vehicles (HV), consisting of buses and trucks;

c. Motorcycle (MC).

In terms of observations in units of time, the traffic volume was calculated using the following formula [3].

$$
\mathrm{q}=\frac{n}{t}
$$

\subsection{Trip Generation / Movement}

In simple terms, it can be defined that the number of trips is the result of the function of land use/area/zone. In addition, it can be formed into a simple model, as shown in the following functional equation [4].

$$
\begin{aligned}
& \operatorname{Trip}\left(\mathrm{Q}_{\text {Trip }}\right)=\mathrm{f}(\mathrm{TGL}) \\
& \text { Where: } \\
& \left(Q_{\text {Trip }}\right)=\text { number of trips arising from land use } \\
& \text { (zone) per unit time } \\
& \mathrm{F} \quad=\text { mathematical function } \\
& \text { date }=\text { characteristics and socio-economic }
\end{aligned}
$$

\subsection{Road Capacity Analysis}

Capacity is defined as the maximum flow through a point on the road that can be maintained per unit hour under certain conditions. For two-lane two-way roads, capacity is separated for two-way flows (two-way combinations). Meanwhile, for multi-lane roads, flows are separated per direction, and capacity is determined per lane. The basic equation for determining capacity [5] is as follows.

$$
C=C O x F C W X F C S P X F C S F x F C C S
$$

Where:

$$
\begin{aligned}
C & =\text { Capacity }(\mathrm{PCU} / \text { hour }) \\
C o & =\text { Basic capacity (PCU/hour) } \\
F C W= & \text { Adjustment factor related to traffic lane } \\
& \text { width } \\
F C S P= & \text { Adjustment factor related to directional } \\
& \text { separation } \\
F C S F= & \text { Adjustment factor related to side } \\
& \text { resistance }
\end{aligned}
$$

\subsection{DEGREE OF SATURATION}

The degree of saturation (DS) is defined as the ratio of road current to road capacity, which is used as the main factor in determining the performance level of intersections and road segments. The DS value indicates the presence or absence of problems on the road segment. The basic equation for determining the degree of saturation is as follows.

$$
\begin{aligned}
& D S=\frac{Q}{C} \\
& \text { Where: } \\
& D S=\text { Degree of saturation } \\
& Q=\text { Traffic flow (PCU/hour) } \\
& C=\text { Capacity (PCU/hour) }
\end{aligned}
$$

\subsection{Side Resistance}

Side resistance is activities on the roadside that have an impact on traffic performance. Roadside activities often cause conflicts that affect traffic, especially on road capacity and traffic speed of urban roads [6]. The category of side resistance and its weight factor can be seen in Table 1.

Table 1. The Determination of the Frequency of Side Resistance Occurrences

\begin{tabular}{|l|c|c|}
\hline $\begin{array}{c}\text { Types of Side } \\
\text { Resistance } \\
\text { Occurrences }\end{array}$ & Symbol & Weight \\
\hline Pedestrian & PED & 0.5 \\
\hline Parking vehicles & PSV & 1.0 \\
\hline $\begin{array}{l}\text { Vehicles } \\
\text { entering and } \\
\text { leaving the side } \\
\text { of the road }\end{array}$ & EEV & 0.7 \\
\hline Slow vehicle & SMV & 0.4 \\
\hline
\end{tabular}

\subsection{Level Of Service}

The level of service (LOS) is a provision in measuring the quality of the trip. LOS is a description of the operational conditions of traffic flow in terms of speed, travel time, comfort, freedom of movement, security, and safety. The value of LOS will change along with the increase in traffic volume on a road segment and changes in road geometric conditions. This LOS can be used as a parameter related to the relationship between speed, density, and level of service in a traffic flow.

There are two types of level of service: flowdependent service level and facility-dependent service level [7]. follows

The formula to calculate the level of service is as

$$
\begin{aligned}
& \operatorname{LOS}=\frac{V}{C} \\
& \text { Where: } \\
& \text { LOS }=\text { Level of service } \\
& \mathrm{V}=\text { Traffic volume (PCU/hour) } \\
& \mathrm{C} \quad=\text { Actual capacity (PCU/hour) }
\end{aligned}
$$

The quality of road services can be expressed in the level of service. Furthermore, the level of road service is divided into 6 conditions, from the best to the worst.

The level of road service is determined on an interval scale consisting of 6 levels based on the Regulation of the Minister of Transportation No. KM 14/2006. This level consists of A, B, C, D, E, and F. The standard distribution of road service levels [8] is calculated using the following formula. 


$$
\begin{aligned}
& D S=(3-6) \frac{Q}{C} \\
& \text { Where: } \\
& D S=\text { Degree of saturation } \\
& Q \quad=\text { Traffic flow (PCU/hour) } \\
& C \quad=\text { Capacity (PCU/hour) }
\end{aligned}
$$

\subsection{Parking Space Capacity}

Parking space capacity is the maximum capacity of space to accommodate vehicles, in this case, the volume of vehicles utilizing the parking facilities. Vehicles utilizing parking facilities are counted from the process of arriving in, staying in (parking), and leaving the parking facility. An illustration of the aforementioned condition will describe the size of the capacity of the parking facility. The formula used to express parking capacity is as follows.

$K p=\frac{V p x D}{T s}$

Where:

$\mathrm{KP}=$ Parking capacity (number of lots)

$\mathrm{VP}=$ Parking volume (vehicles/hour)

$\mathrm{D}=$ Average length of parking (hours/vehicle)

Ts $=$ Survey time (hours)

\section{Results And Discussion}

In the previous section, it has been mentioned that this study was conducted on Jalan Pahlawan Revolusi, Gamalama, Ternate, North Maluku. Data collection was carried out from Monday, 2 November 2020 to Saturday, 7 November 2020. The collected data were then analyzed based on the steps in the guidebook [9].

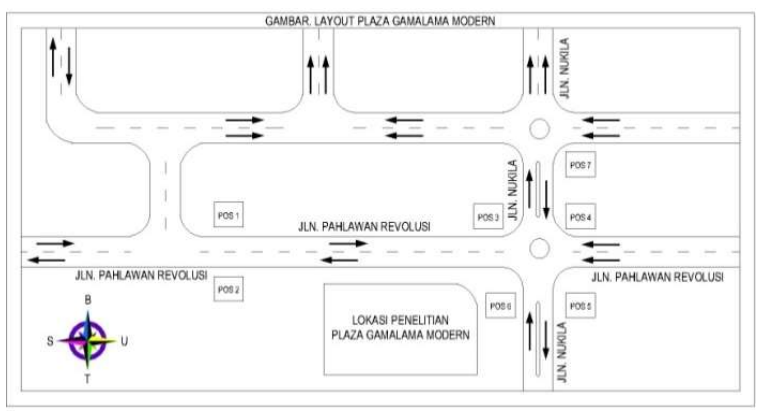

Fig.1. Layout of Plaza Gamalama Modern

\subsection{Geometric Data}

Road geometric data are data concerning the geometric condition of the section under study, in which these data represent the characteristics of the road segment. Geometric conditions consist of a situation plan (land use, road markings, and intersections) and road sections (road width and road shoulder width). The results of measurements and direct visual observations in the field are presented in the following table.
Table 2. Dimensions and Existing Conditions of the

\begin{tabular}{|l|l|c|l|l|l|}
\hline $\begin{array}{l}\text { Name of } \\
\text { the Roads }\end{array}$ & $\begin{array}{l}\text { Type } \\
\text { of the } \\
\text { Road }\end{array}$ & $\begin{array}{l}\text { The } \\
\text { Width } \\
\text { of the } \\
\text { Road } \\
\text { (M) }\end{array}$ & $\begin{array}{l}\text { Road } \\
\text { Marki } \\
\text { ngs }\end{array}$ & $\begin{array}{l}\text { Medi } \\
\text { an } \\
\text { Widt } \\
\text { h } \\
(\mathrm{M})\end{array}$ & $\begin{array}{l}\text { Road } \\
\text { Shoul } \\
\text { der } \\
\text { Widt } \\
\text { h } \\
(\mathrm{M})\end{array}$ \\
\hline $\begin{array}{l}\text { Jl. } \\
\text { Pahlawan } \\
\text { Revolusi }\end{array}$ & $\begin{array}{l}2 \\
\text { undivi } \\
\text { ded } \\
\text { lanes }\end{array}$ & $\begin{array}{l}10 . \\
10\end{array}$ & $\begin{array}{l}\text { Availa } \\
\text { ble }\end{array}$ & - & $<0.5$ \\
\hline Jl. Nukila & $\begin{array}{l}\text { Divide } \\
\text { d into 4 } \\
\text { lanes }\end{array}$ & $\begin{array}{l}14 . \\
00\end{array}$ & $\begin{array}{l}\text { Availa } \\
\text { ble }\end{array}$ & 2 & $<0.5$ \\
\hline
\end{tabular}

\subsection{Traffic Volume Analysis}

Traffic volume analysis is carried by analyzing traffic characteristics. This analysis is meant to gain daily traffic volume. Traffic volume is measured in passenger car units (PCU). In this study, data collection began from Monday, 2 November 2020 to 7 November 2020 on Jalan Pahlawan Revolusi and Jalan Nukila, Ternate. The collected data can be seen in Figures 2 and 3.

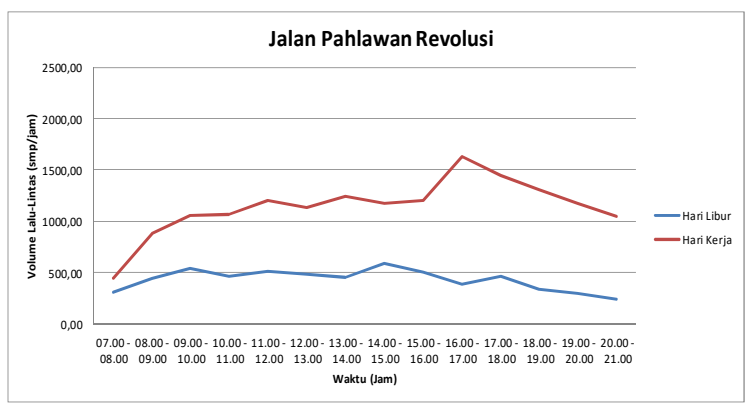

Fig. 2. Graph of traffic volume on Jalan Pahlawan Revolusi during peak hour

As seen in Figure 2, the peak of the maximum traffic volume for Jalan Pahlawan Revolusi occurs on Monday at $16.00-17.00$, which is $1630.6 \mathrm{PCU} /$ hour.

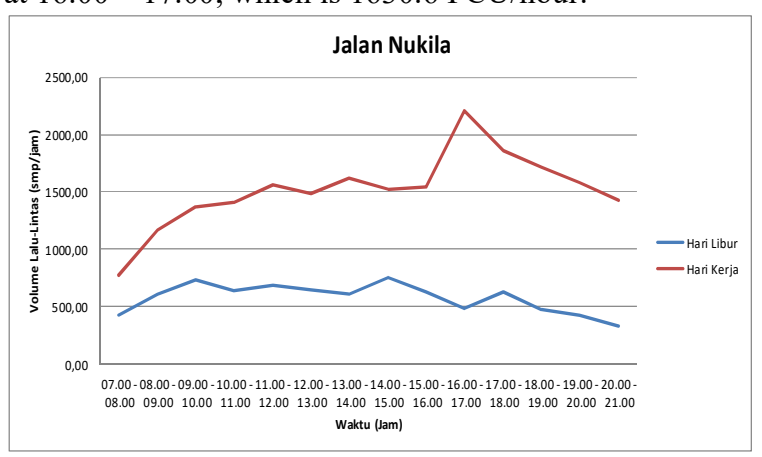

Fig.3. Graph of traffic volume on Jalan Nukila during peak hour

As seen in Figure 3, the peak of the maximum traffic volume for Jalan Nukila occurs on Monday at 16.00 17.00, which is $2202.7 \mathrm{PCU} /$ hour. 


\subsection{Road Capacity Analysis}

Capacity is the maximum traffic flow that can be maintained under certain conditions (geometric condition, directional distribution, traffic composition, and environmental factor). Capacity is one of the factors used to determine the degree of saturation (DS).

Calculating the capacity of the road segment is carried out by determining the values that are used as the basis for calculating the capacity, namely the basic capacity, and several reduction factors.

$$
\mathrm{C}=\mathrm{Co} \times \mathrm{FCw} \times \mathrm{FCsp} \times \mathrm{FCsf} \times \mathrm{FCcs}
$$

Analysis of the capacity of Jalan Pahlawan Revolusi and Jalan Nukila are elaborated below.

A. Jalan Nukila

The basic capacity of this road is 1500 PCU/hour/lane. Therefore, for four lanes, it is 6000 $\mathrm{PCU} /$ hour. The value for road capacity adjustment is 0.92 , the value for direction adjustment factor is 1 , the value for side resistance adjustment is 0.84 , and the value for city capacity adjustment is 0.82 . Total Capacity $=6000 \times 0.92 \times 1 \times 0.84 \times 0.82=$ 3802.2 PCU/hour

Therefore, the capacity of Jalan Nukila is 3802.2 PCU/hour.

B. Jalan Pahlawan Revolusi

The basic capacity of this road is 2900 PCU/hour. The value for road capacity adjustment is 1.29 , the value for direction adjustment factor is 1 , the value for side resistance adjustment is 0.82 , and the value for city capacity adjustment is 0.82 .

Total capacity $=2900 \times 1.29 \times 1 \times 0.82 \times 0.82=$ 2515.4 PCU/hour

Therefore, the capacity of Jalan Pahlawan Revolusi is 2515.4 PCU/hour.

Table 3. Road Capacity on Each Road Section

\begin{tabular}{|c|c|c|}
\hline No. & Roads & $\begin{array}{c}\text { Road capacity } \\
\text { (pcu/hour) }\end{array}$ \\
\hline 1 & Nukila & 3802.2 \\
\hline 2 & Pahlawan Revolusi & 2515.4 \\
\hline
\end{tabular}

\subsection{Degree Of Saturation}

The degree of saturation is the ratio of traffic flow (PCU/hour) to the capacity of a certain road segment (PCU/hour), where DS is used as a parameter to determine the level of road service. The value of the degree of saturation indicates whether a road segment has capacity problems.

The degree of saturation can be calculated using the following formula.

$$
\mathrm{DS}=\mathrm{Q} / \mathrm{C}
$$

Table 4. Degree of Saturation based on the Existing Condition of Each Road Section in 2021

\begin{tabular}{|c|c|c|}
\hline Roads & $\begin{array}{c}\text { Q } \\
\text { Total Flow LL } \\
\text { (PCU/hour) }\end{array}$ & $\begin{array}{c}\text { C } \\
\text { Capacity } \\
\text { (PCU/hour) }\end{array}$ \\
\hline $\begin{array}{c}\text { Nukila } \\
\text { (Workdays) }\end{array}$ & 2202.7 & 3802.2 \\
\hline $\begin{array}{c}\text { Nukila } \\
\text { (Holiday/ } \\
\text { Weekend) }\end{array}$ & 753.4 & 3802.2 \\
\hline $\begin{array}{c}\text { Pahlawan } \\
\text { Revolusi } \\
\text { (Workdays) }\end{array}$ & 1630.60 & 2515.4 \\
\hline $\begin{array}{c}\text { Pahlawan } \\
\text { Revolusi } \\
\text { (Holiday/ } \\
\text { Weekend) }\end{array}$ & 588.10 & 2515.4 \\
\hline
\end{tabular}

\subsection{Prediction Of Visitors Who Will Visit Plaza Gamalama Modern}

The number of visitors to Plaza Gamalama Modern based on the attraction data analysis is shown in Table 5.

Table 5. Prediction of the Number of Initial Visitors to the Opening of Plaza Gamalama Modern

\begin{tabular}{|c|l|c|}
\hline No. & \multicolumn{1}{|c|}{ Origin } & Visitors \\
\hline 1 & North Ternate & 3955 \\
\hline 2 & Central Ternate & 4502 \\
\hline 3 & South Ternate & 5933 \\
\hline 4 & Ternate Island & 841 \\
\hline 5 & Tidore & 547 \\
\hline \multicolumn{2}{|c|}{ Total } & 15778 \\
\hline
\end{tabular}

The equation to determine the estimated number of visitors in the following years is as follows.

$$
\mathrm{P}=\mathrm{Po}(1+\mathrm{i}) \mathrm{n}
$$

Where:

$$
\begin{aligned}
& \mathrm{P} \quad=\text { Number of visitors in year } n \\
& \mathrm{Po}=\text { Number of visitors in the first year } \\
& \mathrm{i} \quad=\text { Population growth rate } \\
& \mathrm{n} \quad=\text { Time (years) }
\end{aligned}
$$

\subsection{Level Of Service Before and After The Operation Of The Plaza}

The level of service (LOS) can be determined by calculating the ratio between the traffic volume and the basic road capacity $(\mathrm{V} / \mathrm{C})$. The obtained LOS value can be used to determine the classification of the road or the level of service on the road segment. 
Table 6. Level of Service After the Operation of the Plaza

\begin{tabular}{|c|c|c|}
\hline Roads & $\begin{array}{c}\text { Level of } \\
\text { Service } \\
\text { (Before) }\end{array}$ & $\begin{array}{c}\text { Level of } \\
\text { Service } \\
\text { (After) }\end{array}$ \\
\hline $\begin{array}{c}\text { Pahlawan } \\
\text { Revolusi } \\
\text { (Workdays) }\end{array}$ & 0.65 (C) & 0.84 (D) \\
\hline $\begin{array}{c}\text { Pahlawan } \\
\text { Revolusi } \\
\text { (Holiday/ } \\
\text { Weekend) }\end{array}$ & 0.23 (B) & 0.43 (B) \\
\hline $\begin{array}{c}\text { Nukila } \\
\text { (Workdays) }\end{array}$ & 0.58 (C) & $0.71(\mathrm{C})$ \\
\hline $\begin{array}{c}\text { Nukila } \\
\text { (Holiday/ } \\
\text { Weekend) }\end{array}$ & 0.20 (A) & $0.33(\mathrm{~B})$ \\
\hline
\end{tabular}

\subsection{The Prediction Of Parking Capacity In The Area Of Plaza Gamalama Modern}

The magnitude of the attraction that occurs due to the construction of Plaza Gamalama Modern can be calculated based on the number of vehicles parked at Plaza Gamalama Modern.

Table 7. Prediction of Car Parking in the Next 10 Years

\begin{tabular}{|c|c|c|}
\hline Years & Turnover & Parking Index \\
\hline 2021 & 1.95 & 195 \\
\hline 2022 & 2.13 & 212.94 \\
\hline 2023 & 2.33 & 232.53 \\
\hline 2024 & 2.54 & 253.92 \\
\hline 2025 & 2.77 & 277.28 \\
\hline 2026 & 2.03 & 302.79 \\
\hline 2027 & 3.31 & 330.65 \\
\hline 2028 & 3.61 & 361.07 \\
\hline 2029 & 3.94 & 394.29 \\
\hline 2030 & 4.31 & 430.56 \\
\hline 2031 & 4.70 & 470.18 \\
\hline
\end{tabular}

At the beginning of the operation of Plaza Gamalam Modern, the car parking capacity was not able to accommodate the number of visitors who would park the car. This can be seen in Table 7, in which the parked vehicles exceed the capacity provided by Plaza Gamalama Modern.

\section{Conclusion}

Based on data from surveys, analysis, and calculations, it can be concluded as follows.

1. From 15 equations applied, the value of $\mathrm{Y}$ is $2.64080272306193 \mathrm{X} 2+4.05031889744212 \mathrm{E}-$ $06 \mathrm{X} 3+0.0882328648259467 \mathrm{X} 4+$ $0.752392757509762 X 5+22.7120066091058$, in which the value of $r$ and $\mathrm{R}$ is 0.543 , the coefficient of determination is 0.548 , a value of significance is 0.000 , and an $\mathrm{f}$ value is 111.886 . From these equations, it is found that the number of visitors to Plaza Gamalama Modern is 15778 which increases to 17600 in the next 5 years and 19633 in the next 10 years.

2. It is recorded that, for Jalan Pahlawan Revolusi, the heaviest volume of vehicles due to existing traffic occurs on Monday at $16.00-17.00$ with a capacity of 2515.4 PCU/hour. In the peak hour, the volume of vehicles reaches 1630.6 PCU/hour. Furthermore, in the peak hour after the plaza operates, it reaches 2123.32 PCU/hour. Meanwhile, for Jalan Nukila, the capacity of this road is $3802.2 \mathrm{PCU} /$ hour. In the peak hour, the volume of vehicles reaches 2202.7 PCU/hour. Furthermore, in the peak hour after the plaza operates, it reaches 2695.42 PCU/hour.

3 . The provided parking capacity for four-wheeled vehicles at Plaza Gamalama Modern is for 60 cars, which cannot accommodate visitor vehicles that will park. This is seen by the turnover of the fourwheel parking capacity at the beginning of the operation, namely $1.95>1.00$. For the next 5 years, it will be $3.03>1.00$. Meanwhile, for the next 10 years, it will be $4.70>1.00$.

\section{References}

1. Abdul, Gaus.. Estimasi distribusi pergerakan arus lalu lintas di kota Ternate dengan menggunakan metode detroit, Universitas Khairun Ternate. (2012).

2. Alin, Mursalin. 2014. Klasifikasi Jalan Menurut Fungsi(http://www.academia.edu/14470932/Klasif ikasi_Jalan_According_Fungsi, diakses 28 Juni (2016).

3. Anonim. Manual Kapasitas Jalan Indonesia (MKJI), Direktorat Jenderal Bina Marga, Departemen Pekerjaan Umum, Jakarta.

4. Andartomo, Zulfikar. 2020, Memprediksi Bangkitan Arus Lalu Lintas Yang Terjadi Akibat Adanya Plaza Gamalama Modern, Universitas Khairun Ternate.

5. Nurrahim, Aditya. Kinerja Lalu Lintas Pada Ruas Jalan Yang Dipengaruhi oleh Adanya Pusat Kegiatan Plaza Gamalama Modern, Universitas Khairun, Ternate, (2020).

6. Sarbin, Firsandi., Memprediksi Besaran Kapasitas Parkir Pada Plaza Gamalama Modern, Universitas Khairun, Ternate, 2020.

7. Tamin Ofzar Z, Perencanaan dan Pemodelan Transportasi, Edisi Kedua, Institut Teknologi Bandung, Bandung, (2000).

8. Tamin Ofzar Z, Perencanaan dan Pemodelan Transportasi, Institut Teknologi Bandung (ITB), Bandung.

9. Undang-Undang No. 22 Tahun 2009, Tentang Lalu Lintas 